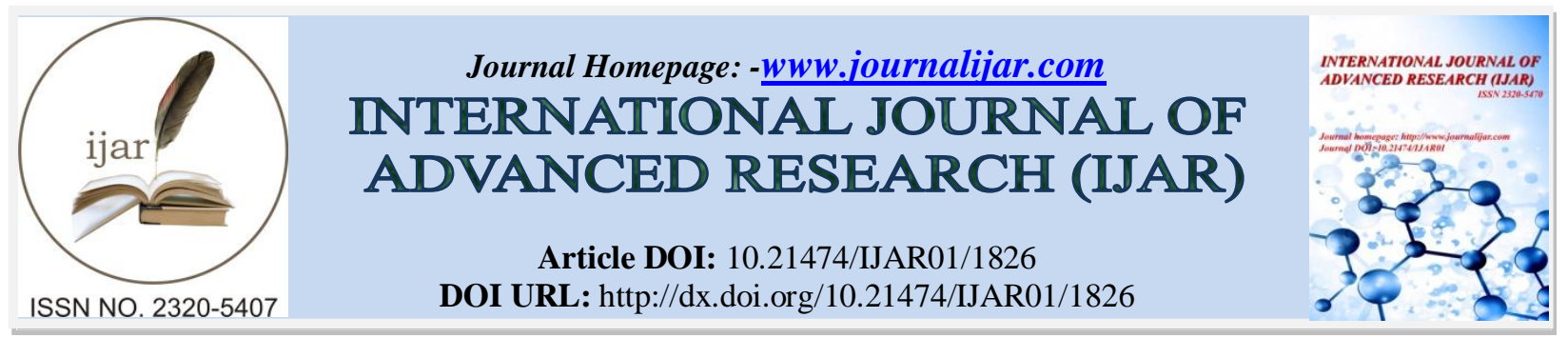

RESEARCH ARTICLE

\title{
EFFECT OF 790-805NM DIODE LASER THERAPY ON MAST CELL IN CUTANEOUS WOUND HEALING IN MICE.
}

Warkaa. M. Ali AL -Wattar.

Lecturer -Department of Oral Pathology-College of Dentistry-AL-Mustansiriyia University-Baghdad-Iraq.

\section{Manuscript Info}

Manuscript History

Received: 16 August 2016

Final Accepted: 16 September 2016

Published: October 2016

Key words:-

Biostimulation, low level laser therapy (LLLT).

\section{Abstract}

Background and objective: -The use of low level laser therapy (LLLT) has been increased now a dayto accelerate healing of soft tissue injuries because of some biostimulatory effects. The goal of this study was to investigate the effect of $790-805 \mathrm{~nm}$ diode laser on the inflammatory effect of mast cells during wound healing in rodents.

Materials and Methods: -A cut wound $(1.5 \mathrm{~cm})$ wasmadeon the cheek of 40albino mice. 20 of them exposed to LLLT $(360 \mathrm{~J} / \mathrm{cm} \mathrm{2})$ at $790-805 \mathrm{~nm}$ immediately post wounding procedure. The animals were scarified and the wound area was prepared and stained by toluidine blue.

Results: - Mean mast cell count of 10.2 in the first day of control group while in laser group 8.4. The control and laser group showed gradual inclination in the mean value to be return to increase at the day 14 of experiment. There was significant difference $(\mathrm{P}<0.05)$ in control group at the first day. While significant difference $(\mathrm{P} \leq 0.05)$ was in the day 7. Pearson correlation showed significant correlation $(\mathrm{P} \leq 0.01)$ between the control group at the day 1 and the laser group at the day 7. While there was significant correlation $(\mathrm{P} \leq 0.05)$ between the control group at the day 14 and laser group at the day 1 .

Conclusions:- LLLT may induce an anti-inflammatory effect on wound healing process by its inhibitory action on mast cells; while it may have a biostimulatory effect on the proliferation of mast cells at proliferative phase of wound healing which indirectly affects fibrous tissue regeneration in subcutaneous area.

Copy Right, IJAR, 2016,. All rights reserved.

\section{Introduction:-}

Mast cells can be activated by trauma or immune mediated mechanisms ${ }^{[1]}$; and they are present in mucosaof respiratory and digestive system in addition to the skin. ${ }^{[2]}$ They are arising in the bone marrow from a multipotent CD34+ precursor and distribute throughout the body by circulationto act locally and systemically by releasing inflammatory mediators through degranulation ${ }^{[3]}$.

Mast cellshave been improved to play a role in wound healing by releasing these mediators ${ }^{[4]}$ that are released by mast cells are neuropeptides and cytokines and pro-inflammatory mediators selectively without degranulation particularly IL-1 induces selective release of IL-6 while cortictropin-releasing hormone secreted understress induced the release of vasoculoendothelial growth factor ${ }^{[5]}$. The anti-inflammatory effect of LLLT in wound healing had 
been studied by many researches. This effect vary from accelerating the inflammatory phase by activation of different cells involved in wound healing to deactivation of other types of cells that may be delay the healing process. ${ }^{[6][7][8][9]}$

One of these cells that had been studied for their relation to the application of LLLT was mast cell. The results vary also from activation to inhibition of anti-inflammatory effect ${ }^{[10]}{ }^{111][12][13]}$. The mechanism by which LLLT act on mast cells is still under research. In this study we tried to explain how this mechanism could be occurring.

\section{Materials and methods:-}

40 albino mice were used in our study weighing 100-150 g. They were housed in plastic cages which nurtured properly and kept in a temperature- and humidity- controlled environment at $23{ }^{\circ} \mathrm{C}$ in a $12 / 12$-h day/night light cycle.

\section{Wound procedure:-}

The animals were anesthetized with diethyl ether and $1.5 \mathrm{~cm}^{2}$ standardized cut wound was performed on the face, then they were arbitrarily divided into two chief groups; control and laser (20 each), then subdivided into four groups(5 each) as fellow: day 1, 3, 7 and 14group.

\section{Laser procedure:-}

Animals inlaser groups were exposed toArGaAl laser beam of 790-805-nm wavelength gotten from a laser device (K-LASER-ITALY) immediately following surgical procedure. The laser beam characters consisted of 780-905 nm for $90 \mathrm{~s}, 4 \mathrm{~W}$ (output power), and an energy density of $360 \mathrm{~J} / \mathrm{cm} 2$ and focal spot was $8 \mathrm{~mm}$. Laser beam was directly positioned over wound without contact $(0.5 \mathrm{~cm})$ away from the edge of the wound with one spot to cover the wound area.

\section{Histological procedure:-}

The animals were sacrificed by overdose of diethyl ether in closed jar then; the histological specimens were taken from wound and adjacent areas. The specimens were fixed in buffered $10 \%$ formalin, and then embeddedin paraffin. Many sections of $5 \mu \mathrm{m}$ thickness were taken from each block and put on microscopic slides.

Toluidine blue stain ( $1 \%$ toluidine blue in $1 \%$ sodium chloride) was used as a special stain for enumeration of mast cells. Both intact and degranulated mast cells were recorded under high magnification of light microscope (oil lens x1000) for counting. Five fields from high power view for each specimen's slide were used to obtain the data results.

\section{Ethical considerations:-}

The study was led in full agreement with the World Medical Association Declaration of Helsinki. Before starting the study; astudy proposal was submitted, and approved bythe InstitutionalEthical Committeein Baghdad UniversityCollege of Dentistry.

\section{Statistical analysis:-}

Statistical Package for Social Sciences, Windows 7, software version 14 (SPSS)was used to process the data gained. Descriptive, ANOVA, Persons correlation were used to obtain the results.

\section{Results:-}

Microscopical viewing of the histological slides is seen in figures (1-4) for both control and laser group. The observations of the sections showed no obvious variance in the distribution of mast cells between the two groups. 


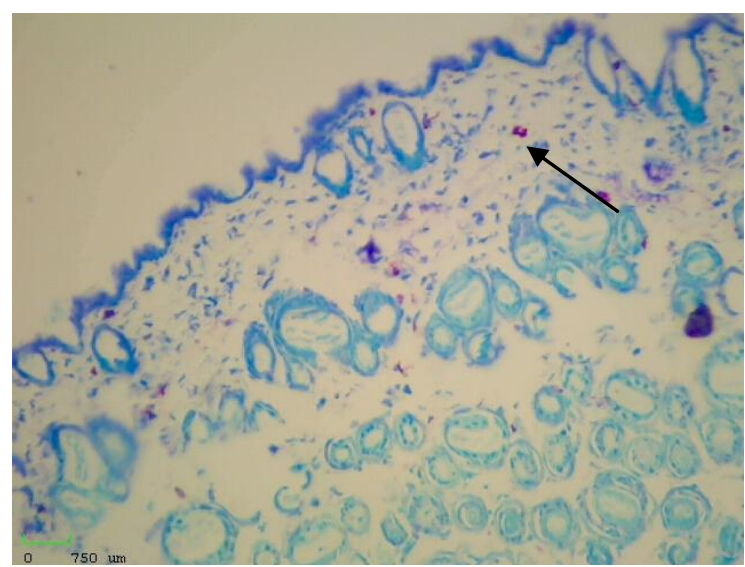

Figure-1:- Site of the wound in control group at day 1 showed proliferation of mast cells (pointed) x20

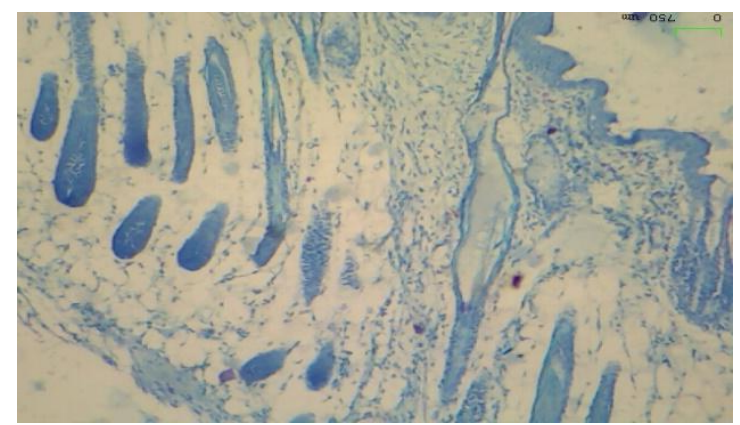

Figure 2:- Wound healing area at day 14 showed marked reduction in mast cells count x10

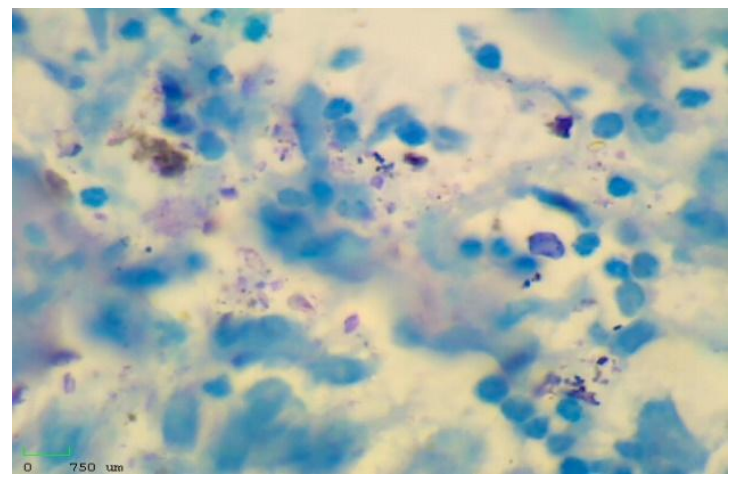

Figure 3:- Wound healing area in laser group at day 3 in sub-epithelial area x100.

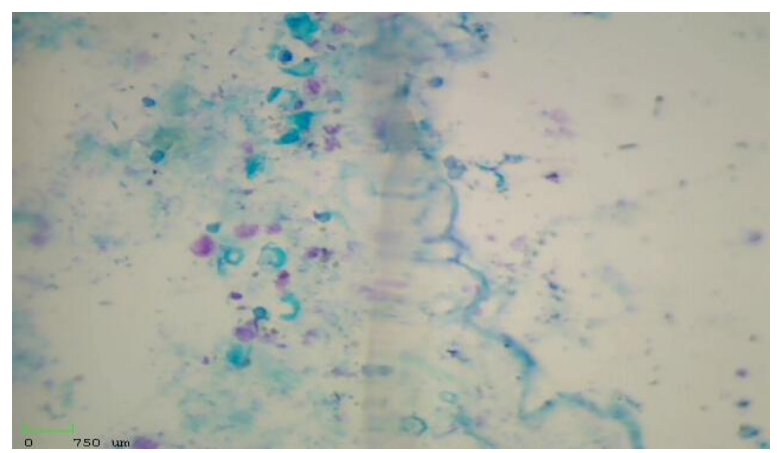

Figure 4:- Wound healing area in laser group at day 14 X10 
(Table 1) showed mean value of mast cell count of (10.2) in the day 1 of control group while in laser group (8.4). Both the control and laser group showed gradual inclination in the mean value at day 3 to be return to increase at the day 7 of experiment. The laser group showed high mean value of mast cells (9) at day 14 than control group.

Table 1:-mean value, standard error and standard deviation of total mast cell number.

\begin{tabular}{|l|c|c|c|}
\hline \multirow{2}{*}{ group } & Mean & Standard error & \multirow{2}{*}{ Standard deviation } \\
\cline { 2 - 3 } & statistic & 5.774 & 12.911 \\
\hline Control 1 & 10.2 & 4.19 & 9.37 \\
\hline Laser 1 & 8.4 & 2.244 & 5.019 \\
\hline Control 3 & 7.2 & .836 & 1.87 \\
\hline Laser 3 & 5 & 1.224 & 2.733 \\
\hline Control 7 & 8.6 & 2.4 & 5.366 \\
\hline Laser 7 & 5 & 1.496 & 3.346 \\
\hline Control 14 & 7.2 & 2.07 & 4.636 \\
\hline Laser 14 & 9 & & \\
\hline
\end{tabular}

(Table 2) showedstaticallysignificant difference $(\mathrm{P} \leq 0.05)$ in control group at the day 1 .

Table 2:-ANOVA test between groups.

\begin{tabular}{|l|l|l|l|l|}
\hline group & Sum of square & Mean square & F value & Sig. \\
\hline Control 1 & 666.3 & 222.1 & 444.2 & $.035^{*}$ \\
\hline Laser 1 & 109.2 & 36.4 & .15 & .918 \\
\hline Control 3 & 68.8 & 22.933 & .717 & .677 \\
\hline Laser 3 & 14 & 4.667 & - & - \\
\hline Control 7 & 29.5 & 9.833 & 19.667 & .167 \\
\hline Laser 7 & 114.7 & 38.233 & 76.46 & .084 \\
\hline Control 14 & 42.8 & 14.267 & 7.133 & .267 \\
\hline Laser 14 & 45.5 & 15.167 & .374 & .799 \\
\hline
\end{tabular}

Pearson correlation showed significant difference $(\mathrm{P} \leq 0.01)$ between the control group at the day 1 and the laser group at the day 7 .

While there was significant difference $(\mathrm{P} \leq 0.05)$ between the control group at the day14 and laser group at the day 1 . (Table 3).

Table 3:-Pearson correlation between control and laser group.

\begin{tabular}{|l|l|l|}
\hline Pearson correlation & Laser7 & Laser1 \\
\hline Control 1 & $.997^{* *}$ & \\
\hline Control14 & & $.953^{*}$ \\
\hline
\end{tabular}

** At level 0.01

At level 0.05

\section{Discussion:-}

Wound healing represents one of the most common fields that use LLLT in variousresearches and clinical studiesinhumans. ${ }^{[14-17]}$ Additional studies in animals has also reinforced the role of LLLT inaccelerating wound healing ${ }^{[18-19]}$ In contrast, many investigators proved that there was no benefitin healing by usingLLLT ${ }^{[20-23]}$ The concept of light absorption is specific to cell and tissue type and the variations between tissues in the same organcould be seen ${ }^{[24]}$ decreasing the ability to generalize the outcomes of animal data resultson human wounds. The molecular level of clinical trials and researches could be more informative about the specific cells and structures that affected by laser therapy.

The results of our study in day 1 showed increased in mast cells' count in control group in comparison to laser group. This count made a greater difference in mean value(8.6) at day 7 in control group.

On day 14, the laser group exhibited means 9 of mast cellshigher than control group. This result disagree with that of Bayat et al, and Vasheghani ${ }^{[10-11]}$ who found that LLLT effects significantly on the increase of total number of mast cells during the inflammatory phase of wound healing in the experimental third degree burns. 
This difference may be due the type of laser and type of wound. In contrast there was major increase in the overall number of mast cells in day 7 up to the day 14 in laser group which represents the phase of proliferation and remodeling in wound healing process.

This disagreed with the results of DeCastro etal ${ }^{[25]}$ who approved that mast cells affect the proliferation of fibroblast and there was a correlation between their number and myofibroblasts in control wound repair but in the excisional wound treated with laser; there was increased in collagen deposition in relation to reduction in mast cells 'count.

Though both groups showed complete healed wounds without complications because there was no sign of infection, clinically by day 14; buton cellular level; LLLT appeared to accelerate the remodeling phase of healing, in which the granulation tissue would be converted to more strong fibrous connective tissue.

The effect of use of LLLT on mast cells in cutaneous wound and it's effect on wound healing was performed by many clinicians and investigators to investigate the most beneficial use of specific therapeutic modality.These studies have been done on different types of wounds and correlate the results with different types of laser,laser devices and frequenciesconcluded that many errors in the methods among studies made using LLLT did not allowsufficient conclusions to be tired relative to the value of the modality. ${ }^{[27-31]}$

These studies didn't explain and quantify the actual differences between laser and non-laser-treated wounds and many of them often employ a variety of approachesin the same study; which makes it difficult to evaluate the effects of a single parameter. The cellular level of investigation forseveral intrinsic and extrinsic factors relatedto the inflammatory response and healing make well-designed studyis more reliable.

The precise mechanism by which LLLT accelerates wound healing isstill unknown. But some theories could explain how laser energy stimulates cells in wound healing. In some of thesestudies that were experimental; have shown an increase in fibroblast count after irradiation ${ }^{[32]}$ suggesting that LLLT may accelerate fibroblasts proliferation during the remodeling phase of wound healing which support our results in this study. We found that LLLT has a significant difference at day 7, when wounds start to be in the remodeling phase of cutaneous healing. However; other studies found no in vitro changes in fibroblast count after LLLT ${ }^{[33-35]}$. This could be due to difference in laser device settings, such as wavelength, duration, power density, and intensity ${ }^{[24]}$

Accelerated wound contraction could be explained by the work of Pourreau-Schneider et al ${ }^{[36]}$ who showed that LLLT transforms fibroblasts into myofibroblasts which are mainly involved in granulation tissue contraction, so increased their count could accelerate wound contraction. The role of mast cells seems to affect the proliferation of fibroblast and there was a correlation between their number and myofibroblasts in control wound repair. ${ }^{[3]}$

The mechanism by which the two edges of wound become close and causingcontraction of granulation tissue is by the action of cytoplasmic fibrils of actomyosinin of myofibroblasts and thenreducing the size of the wound during the remodeling phase of healing process. ${ }^{\text {[37] }}$ Our data providing support to the fact of that LLLT enhanced wound healing by its stimulate the proliferation of mast cells hence fibroblasts proliferation but not necessarily enhance other variables associated with wound healing

This study showed that LLLT may have an indirect effect on wound's surrounding tissues. Both the laser exposed and unexposed wounds showed enhancement of healing. These data are agreed with that of Braverman et al, ${ }^{[38]}$ who found that both control and laser group showed the same results of wound healing. This may be due to release of growth factors into circulation, then affect surrounding tissues or other parts of the body. Mast cells may modify inflammatory response by playing a role in neoangiogenesis and tissue remodeling ${ }^{\text {[3] }}$. This is an indirect effect onhealing thatcould be a very valuable effect of this modality in treating tissue injury of large size, multiple sites, and deep woundsthat could be affected by laser therapy.

The uniform wound model in this studywasrestricted to acute, full skin thickness incisional wounds that extend into the dermis that may show the same healing process to that in other types of tissuesin the body, but there was no obvious results that similar effects of LLLT would be seen in wounds of other sites or in chronic woundsalthough mast cells both acute and chronic inflammation due to different types of inflammatory mediators released from them.Among these mediators are histamine, heparin, hyaluronic acid, proteoglycans, proteases growth factors, and cytokines ${ }^{[3]}$. 
The results in this study wererelated to the specific device settings. These settings reflect common clinical practice and the manufacturer's recommendations and guidelines. ${ }^{[15]} 790-805 \mathrm{~nm}$ diodes represents a common clinical practice diode lasers ${ }^{[24]}$ there may be a gap between the head of the probe and the wound and some assumed divergence of the laser light and reduction of irradiation intensity to the tissue. The variations was seen from other studies could be due to be the result of individual differences in tissue elasticity and compliance among different animals' model.

\section{Conclusions:-}

Mast cells proliferation and degranulation could be affected by LLLT in wound if applied directly after the trauma or wound process. This stimulation may be less than normal wound healing in the inflammatory phase but would be more in the proliferation phase.

\section{References:-}

1. Luisa A. D . Neutrophils and Mast Cells in Wound Healing. Advances in Wound Care: Volume 1.Publisher: Mary Ann Liebert,2011

2. Sudhakar R, Ramesh V, Balamurali PD, Oza N, Premalatha B, Karthikshree V." Incidence of mast cells in oralinflammatory lesions a pilot study". J Oral MaxillofacialPathol 2005;9:12-5.

3. Martin P, Leibovich SJ. "Inflammatory cells during wound repair: the good, the bad and the ugly". Trends Cell Biol.2005 Nov;15(11):599-607. Epub 2005 Oct 3.

4. Weller K, Foitzik K, Paus R, Syska W, Maurer M. "Mast cells are required for normal healing of skin wounds in mice". FASEB J 2006; 20: 2366-2368.

5. Theoharis C., Theoharides K., DionysiosAl., Asimenia A., Danae A. D., Nikolaos S. "Mast cells and inflammation".Biochimca et BiophysicaActa(BBA) Molecular Basis of Disease,2012;1822 (1):21-33.

6. Chow RT, Barnsley L. "Systematic review of the literature of low-level laser therapy (LLLT) in medicine". Laser Surg.Med. 2005; 37:46-52.

7. GhamsariSM,Taguchi K,Abe N, Acorda JA, Motoyoshi S and Yamoda H." Evaluation of LLLT on primary healing of experimentally induced full skin wound". Vet. Surg. 1997; 26(2): 114-20.

8. Mehdi IS. "Enhancement of surgical wound healing by LLLT with topical Gention violet". Diploma dissertation in laser application in medicine submitted to Institute of Laser for post graduate studies, University of Baghdad, 2004.

9. Petersen SL, BotesC,Olivier A, Guthrie Aj. "The effect of LLLT on wound healing in horses". Equine Vet.J.Marg. 1999; 31(3):228-31.

10. Bayat M, Vasheghani MM, Razavie N, Jalili MR." Effects of low-level laser therapy on mast cell number and degranulation in third-degree burns of rats".JRehabil Res Dev.2008;45(6):931-8.

11. Vasheghani MM, Bayat M, Rezaei F, Bayat A, Karimipour M." Effect of low-level laser therapy on mast cells in second-degree burns in rats. Photomed Laser Surg". 2008 Feb;26(1):1-5.

12. Pereira MC, de Pinho CB, Medrado AR, Andrade Zde A, Reis SR."Influence of 670 nm low-level laser therapy on mast cells and vascular response of cutaneous injuries".J PhotochemPhotobiol B. 2010 Mar 8;98(3):188-92.

13. Pinfildi CE, Liebano RE, Hochman BS, Enokihara MM, Lippert R, Gobbato RC, et al. "Effect of low-level laser therapy on mast cells in viability of the transverse rectus abdominis musculocutaneous flap".Photomed Laser Surg. 2009 Apr;27(2):337-43.

14. Baxter GD. Therapeutic Lasers: Theory and Practice. Edinburgh, UK: Churchill Livingstone; 1994.

15. Chromey PA. "The efficacy of carbon dioxide laser surgery for adjunct ulcer therapy". ClinPodiat Med Surg. 1992;9:709-719.

16. Gogia PP, Hurt BS, Zirn TT. "Wound management with whirlpool and infrared cold laser treatment: a clinical report". Phys Ther. 1988;68:1239-1242.

17. Schindl A, Schindl M, Schindl L. "Successful treatment of persistent radiation ulcer by low power laser therapy. J Am AcadDermatol". 1997;37:646-648.

18. Schindl M, Kerschan K, Schindl A, Schon H, Heinzl H, Schindl L." Induction of complete wound healing in recalcitrant ulcers by low-intensity laser irradiation depends on ulcer cause and size". PhotodermatolPhotoimmunolPhotomed. 1999;15:18-21.

19. Dyson M, Young S. "Effect of laser therapy on wound contraction and cellularity in mice". Lasers Med Sci. 1986;1:126-130.

20. Mester E, Jaszsagi-Nagi E. "The effect of laser radiation on wound healing and collagen synthesis". StudiaBiophys. 1973;35:227-230. 
21. Allendorf JD, Bessler M, Huang J." Helium-neon laser irradiation at fluences of 1,2 , and $4 \mathrm{~J} / \mathrm{cm}^{2}$ failed to accelerate wound healing as assessed by wound contracture rate and tensile strength". Lasers.Surg Med. 1997;20:340-345.

22. Hunter J, Leonard L, Wilson R, Snider G, Dixon J." Effects of low energy laser on wound healing in a porcine model". Lasers Surg Med. 1984;3:285-290.

23. Lundeberg T, Malm M. "Low-power HeNe laser treatment of venous leg ulcers". Ann Plastic Surg.1991;27:537-539.

24. Saperia D, Glassberg E, Lyons RF. "Demonstration of elevated type I and type III procollagen mRNA levels in cutaneous wounds treated with helium-neon laser: proposed mechanism for enhanced wound healing". BiochemBiophys Res Commun. 1986;138:1123-1128.

25. De Castro IC, Rocha CA, Gomes Henriques AC, Cavalcanti de Sousa AP, Lisboa MV, SoteroDda R et al. "Do laser and led phototherapies influence mast cells and myofibroblasts to produce collagen?"Lasers Med Sci. 2014 Jul;29(4):1405-10.

26. Beckerman H, de Bie RA, Bouter LM, De Cuyper HJ, Oostendorp RAB. "The efficacy of laser therapy for musculoskeletal and skin disorders: a criteria-based meta-analysis of randomized clinical trials". Phys Ther. 1992;72:483-491.

27. Brosseau L, Welch V, Wells G." Low level laser therapy for osteoarthritis and rheumatoid arthritis: a metaanalysis". J Rheumatol. 2000;27:1961-1969.

28. DeBie RA, de Vet HCW, Lenssen TF, van den Wildenberg FAJM, Koostra G, Knipschild PG. "Low-level laser therapy in ankle sprains: a randomized clinical trial". Arch Phys Med Rehabil. 1998;79:1415-1420.

29. Gam AN, Thorsen H, Lonnberg F." The effect of low-level laser therapy on musculoskeletal pain: a metaanalysis". Pain. 1993;52:63-66.

30. Gür A, Karakoc M, Nas K, Cevik R, Sarac J, Demir E. "Efficacy of low power laser therapy in fibromyalgia: a single-blind, placebo-controlled trial". Lasers Med Sci. 2002;17:57-61.

31. Simunovic Z, Ivankovich AD, Depolo A. "Wound healing of animal and human body sport and traffic accident injuries using low-level laser therapy treatment: a randomized clinical study of seventy-four patients with control group". J Clin Laser Med Surg. 2000;18:67-73.

32. Saperia D, Glassberg E, Lyons RF." Demonstration of elevated type I and type III procollagen mRNA levels in cutaneous wounds treated with helium-neon laser: proposed mechanism for enhanced wound healing". BiochemBiophys Res Commun. 1986;138:1123-1128.

33. Colver GB, Priestly GC." Failure of HeNe to affect components of wound healing in vitro". Br $\mathrm{J}$ Dermatol.1989;121:179-186.

34. Hallman HO, Basford JR, O'Brien JF, Cummins LA. "Does low-energy helium-neon laser irradiation alter “in vitro" replication of human fibroblasts?" Lasers Surg Med. 1988;8:125-129.

35. Pourreau-Schneider N, Ahmed A, Soudry M. "Helium-neon laser treatment transforms fibroblasts into myofibroblasts". Am J Pathol. 1990;137:171-178.

36. Spector TD, Axford JS. An Introduction to General Pathology. 4th ed. Edinburgh, UK: Churchill Livingstone; 1999.

37. Braverman B, McCarthy RJ, Ivankovich AD, Forde DE, Overfield M, Bapna MS. "Effect of helium-neon and infrared laser irradiation of wound healing in rabbits". Lasers Surg Med. 1989;9:50-58.

38. Nienartowicz A, Sobaniec-Lotowska ME, Jarocka-Cytra E, Lemancewicz D. "Mast cells in neoangiogenesis". Med SciMonit. 2006;12(3):RA53-56. 